\title{
Correction to: Lifetime-scale ontogenetic movement and diets of red grouper inferred using a combination of instantaneous and archival methods
}

\author{
Julie L. Vecchio • Ernst B. Peebles
}

Published online: 3 February 2022

C) Springer Nature B.V. 2022

\section{Correction to: Environ Biol Fish https://doi.org/10.1007/s10641-022-01210-2}

The original published version did not include an Acknowledgements section. The missing Acknowledgements section is as follows:

\section{Acknowledgements}

This work would not have been possible without the tireless contributions of numerous individuals, especially researchers at the Florida Fish and Wildlife Research Institute (FWRI) of the Florida Fish and Wildlife Conservation Commission (FWC). The work of the Fishery Independent Monitoring (FIM) program was indispensable for the completion of this work, especially Dr T. Switzer, and Dr. K. Thompson. FIM field personnel collected the fish specimens used for stable isotope and stomach content analysis. FIM Gut Lab personnel completed all visual identification of stomach contents. FWRI Age and Growth

The original article can be found online at https://doi.org/ 10.1007/s10641-022-01210-2

J. L. Vecchio $(\bowtie) \cdot$ E. B. Peebles

College of Marine Science, University of South Florida, 8301 St South, St. Petersburg, FL 33701, USA

e-mail: jlvsses@gmail.com

J. L. Vecchio

FWC-FWRI, 100 8th Ave SE, St. Petersburg, FL 33701, USA lab provided otolith preparation, aging and measuring facilities. J. Carroll, A. Amick, K. Cook and K. Rynerson all provided invaluable assistance in otolith preparation and aging. M. Schram aged all fish otoliths. NOAA Fisheries laboratory in Panama City, including C. Gardner, contributed fish collected from routine reef fish monitoring. C. Bruger, J. Granneman, A. Wallace, and B. Michaud assisted with eye-lens dissection. All stable isotope values were produced by Dr. E. Goddard in the Paleoceanography lab at the College of Marine Science, USF. This paper is a chapter from JLV's PhD dissertation, which benefitted from input by committee members EBP, Dr. C. Stallings, Dr. S. Murawski, Dr. L. Lombardi, and Dr. B. Rosenheim.

Publisher's note Springer Nature remains neutral with regard to jurisdictional claims in published maps and institutional affiliations. 